\author{
절식대사 시험에 의한 한우 수소의 유지에너지 요구량 결정에 \\ 관한 연구 \\ 이상철·탁태영·김경훈·윤상기 \\ 농촌진흥청 축산기술연구소
}

\title{
Energy Requirements of Growing Hanwoo Bulls for Maintenance by Fasting Metabolism
}

\author{
S. C. Lee, T. Y. Thak, K. H. Kim and S. G. Yoon
}

National Livestock Research Institute, RDA

\begin{abstract}
Net and metabolizable energy requirements for maintenance of Hanwoo (Korean native cattle) bulls were estimated in twenty-eight fasting metabolism trials using seven different feeds at four stages of body weight $(100,200,300$ and $400 \mathrm{~kg})$. Three cattle for each of twenty-eight trials fed at a level of maintenance energy requirement were housed in metabolic stalls during the 5 days of collection period. Thereafter, during the 2 days of respiration period the heat production was measured by indirect calorimetry using respiratory chamber. After finishing the respiratory metabolism trials under the maintenance level, experimental animals were fasted for 5 days and were measured heat production by indirect calorimetry using respiratory chamber. Seven different feeds were: 1) mixed ration of concentrate and rice straw, 2) mixed ration of concentrate and mixed grass hay, 3) mixed ration of concentrate and corn silage, 4) rice straw alone, 5) mixed grass hay alone, 6) corn silage alone, 7) concentrate alone. Fasting heat production were $66.05 / \mathrm{W}^{0.75}$ at $100 \mathrm{~kg}$ of body weight and $60 \sim 63 \mathrm{kcal} / \mathrm{W}^{0.75}$ at $200 \sim 400 \mathrm{~kg}$ of body weight. When subtracting heat loss by muscular work from the fasting heat production, basal metabolic rate was $55.92 \mathrm{kcal} / \mathrm{W}^{0.75}$. The average values of $\mathrm{NEm}$ requirements were obtained by adding urinary energy excretion to the basal metabolic rates were $69.1,62.1,65.8$ and $64.4 \mathrm{kcal} / \mathrm{W}^{0.75}$ for the four stages of body weight, respectively. The ME requirement for maintenance could be calculated using retained energy and the efficiency of utilization of ME for net energy. The ME requirement for maintenance thus obtained was $102.69 \mathrm{kcal} / \mathrm{W}^{0.75}$.
\end{abstract}

(Key words : Energy requirement, Fasting metabolism, Hanwoo, MEm, NEm)

\section{I. 서 론}

가축이 섭취한 영양소는 생산활동과 기본적 인 생명현상을 유지하기 위해 쓰여진다. 그 중 에서 체중의 증감 없이 생명현상만을 유지하기
위해 필요로 하는 영양소의 양을 유지요구량이 라 하는데, 절식시에는 생명유지를 위한 내부 작용, 즉 호흡, 혈액순환, 근육유지, 호르몬분비 등을 계속하기 위해서 체조직을 분해 이용하게 된다. 이러한 체조직의 분해현상을 절식대사

Corresponding author : S. C. Lee, National Livestock Research Institute, R. D. A. Suwon 441-350, Korea Tel : 031-290-1647, E-mail : lee647@rda.go.kr 
(fasting metabolism)라 하고, 조직의 분해가 일 어나지 않도록 하는데 요구되는 최소에너지 요 구량인 유지에너지 요구량은 바로 절식대사로 발생하는 손실을 정확히 보충해 줄 수 있는 량 이 된다. 따라서 절식대사를 구명하는 방법으 로도 유지에너지 요구량을 구할 수 있다.

동물을 이용한 절식대사 시험을 시험축의 움 직임이 전혀 없는 완전 휴식(complete resting) 상태에서 수행할 수 있다면 이때 발생하는 열 발생량(Fasting heat production; FHP)은 기초대 사율(basal metabolic rate)에 해당하겠지만, 시험 축의 완전휴식을 기대하기 어렵기 때문에 근육 활동으로 발생하는 열 발생량을 보정해 주어야 기초대사시의 열 발생량인 유지에 필요한 정미 에너지(NEm)을 구할 수 있다. 또한 유지 수준 의 에너지를 급여하는 조건에서의 에너지 균형 시험을 통해 얻어진 축적에너지(retained energy; $\mathrm{RE}$ )를 이용하여 섭취한 대사에너지를 에너지 평형 상태로 보정하면 유지를 위한 대사에너지 $(\mathrm{MEm})$ 를 구할 수 있다.

이 등(2002)는 한우 수소를 공시하여 유지에 너지 수준과 유지에너지의 1.5 배, 2.0 배의 3 수 준의 에너지를 급여한 에너지 균형시험에서 유 지에 필요한 대사에너지를 $95.80 \mathrm{kcal} / \mathrm{W}^{0.75}$ 라고 하였다. 본 실험에서는 절식대사 시험 방법으 로 한우 수소의 유지를 위한 정미에너지 및 대 사에너지를 구하였다.

\section{II. 재료 및 방법}

체중 $100 \mathrm{~kg}$ 에서 $400 \mathrm{~kg}$ 까지 $100 \mathrm{~kg}$ 증체 간격 $(100,200,300,400 \mathrm{~kg})$ 으로 7 종류의 사료를 각 각 유지에너지 수준(NRC, 1976)만 급여하여 유 지에 필요한 에너지 요구량을 조사하였다. 실 험 I(배합사료+볏짚), 실험 II(배합사료+목건초), 실험 III(배합사료+옥수수 사일리지)은 조사료 와 농후사료의 비율이 40:60으로 하였고, 실험 $\mathrm{IV}, \mathrm{V}, \mathrm{VI}, \mathrm{VII}$ 은 각각 볏짚, 목건초, 옥수수 사 일리지, 배합사료를 단독 급여하였다. 농후사료
는 체중 $100 \mathrm{~kg}$ 시에는 조단백질 $16 \%$, TDN 72 $\%$, 체중 $200 \sim 300 \mathrm{~kg}$ 시에는 조단백질 $14 \%, \mathrm{TDN}$ $71 \%$, 체중 $400 \mathrm{~kg}$ 시에는 조단백질 $12 \%, \mathrm{TDN}$ $70 \%$ 로 각각 체중에 따라 조절 배합하였다. 그 리고 볏짚은 $4 \sim 5 \mathrm{~cm}$ 크기로 절단하여 급여하였 고 목건초는 오차드그라스 주종의 혼합 목건초 를 이용하였다.

시험계획에 의거 사료별 그리고 체중별 대사 시험을 위한 3 두의 공시축은 일반 시험우사에 서 3 주간 해당 사료를 섭취하면서 체내 대사율 이 조절되도록 하였다. 그 후 대사시험동으로 이동시켜 7일간 대사틀 적응과 대사율 조절을 위한 예비시험과 7 일간의 분뇨 채취시험을 실 시하였다. 사료섭취시 열 발생량을 측정하기 위해서 분뇨 채취시험기간 종료 2 일전에 호흡 대사장치로 이동하여 체열 발생량(Heat production)을 측정하였는데 처음 24 시간 동안은 예비 측정 자료로 하였고, 두 번째 24시간 동안의 자료를 본 시험의 자료로 이용하였다. 각각의 사료별 그리고 체중별 사료섭취에 따른 호흡대 사시험을 종료한 후 다시 5일간 완전 절식시켜 (체중 $100 \mathrm{~kg}$ 시 4일) 마지막 24시간 동안 FHP 를 측정하였으며, 절식대사 시험기간동안의 일 별 기립시간과 기복횟수를 측정하였다. 사료는 사료 급여량을 오전 9시 30 분과 오후 5시에 2 회로 분할 급여하였고 물과 칼슘, 인 공급용 린칼블록은 자유 섭취케 하였다.

공시사료는 본시험 7일동안 매일 일정량을 개체별로 따로 수집하여 분석하였으며 매일 채 취한 분은 배설량을 정량한 후 혼합기에서 $15 \sim 20$ 분간 교반하여 $1 / 10$ 량을 채취, $-15^{\circ} \mathrm{C}$ 냉 동실에 보관 하였는데 이러한 과정을 본시험 7 일간 반복하면서 최종적으로 수집된 7일간의 분을 해동 시킨후 다시 교반하여 $1 / 10$ 량을 채 취하여 $60^{\circ} \mathrm{C}$ 송풍건조기에서 48 시간동안 건조 시켜 분석에 임하였다. 그러나 분 질소 함량은 생분 상태로 분석하였다. 뇨는 배설량의 $1 / 10$ 량 을 채취하여 냉동실에 보관 하였으며 7 일간의 뇨를 혼합한 후 그중 $500 \mathrm{cc}$ 를 채취, 질소 및 
열량 측정을 하였다. 분과 뇨의 분의 열량을 측정하기 위해 bomb calorie meter (Shimadzu, $\mathrm{CA}-3$ )를 이용하였으며 기타 성분은 $\mathrm{AOAC}$ (1990)법에 의해 분석하였다.

호흡대사시험 동안의 가스분석을 위해 6900 형 가스채취장치(삼응공업)를 사용하였으며 호 흡시험 개시전에 표준가스를 통과시켜 zero 점 과 $\operatorname{span}$ 점을 맞춘 후 대기중 $\mathrm{CO}_{2}, \mathrm{O}_{2}$ 및 $\mathrm{CH}_{4}$ 농도는 4 분간 30 초 간격으로 분석하였고 호흡 챔버내의 농도는 6 분간 30 초 간격으로 분석하 였다. $\mathrm{CO}_{2}$ 와 $\mathrm{CH}_{4}$ 분석은 적외선 가스분석계, $\mathrm{O}_{2}$ 는 자기식 산소분석계를 사용하였다(이, 1991). 열 발생량의 계산은 다음의 Brouwer (1965) 공 식을 인용하였다.

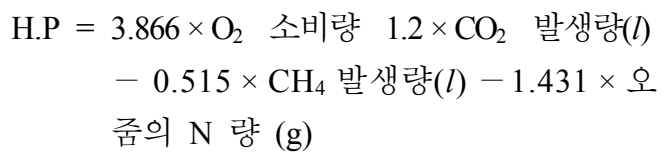

\section{III. 결과 및 고찰}

1. 급여사료의 소화율과 사료가치

체중별로 공시된 한우 수소의 평균 체중은 체중 $100 \mathrm{~kg}$ 시 $97 \sim 151 \mathrm{~kg}, 200 \mathrm{~kg}$ 시 $188 \sim 238 \mathrm{~kg}$, $300 \mathrm{~kg}$ 시 $269 \sim 324 \mathrm{~kg}, 400 \mathrm{~kg}$ 시 $371 \sim 417 \mathrm{~kg}$ 의 범
위였다. 본 시험에서 측정된 각 조사료 및 배 합사료의 사료가치는 볏짚의 경우 DCP $1.7 \%$, $\mathrm{TDN} 48 \%$ 로 한국표준사료성분표(1988)의 DCP $1.9 \%$ 및 $\mathrm{TDN} 43 \%$ 에 비해 $\mathrm{DCP}$ 는 약간 낮고 $\mathrm{TDN}$ 은 약간 높게 평가되었으나 한국사료성분 표(1982)의 TDN $48 \%$ 와는 비슷한 경향이었다. 그러나 옥수수 사일리지는 $\mathrm{DCP} 5.5 \%, \mathrm{TDN}$ $59 \%$ 로 한국표준사료성분표(1988)의 옥수수 사 일리지의 황숙기 성적과 비교할 때 $\mathrm{DCP}$ 함량 은 비슷하였으나 $\mathrm{TDN}$ 함량이 약 $5 \%$ 정도 낮 게 평가되었고 한국사료성분표(1982)의 $\mathrm{DCP}$ $4.1 \%, \mathrm{TDN} 62 \%$ 에 비해 $\mathrm{DCP}$ 함량은 높았으며 $\mathrm{TDN}$ 함량은 비슷하였지만 $\mathrm{NRC(1984)의} \mathrm{TDN}$ $70 \%$ 에 비해서는 매우 낮았다. 혼합목건초는 $\mathrm{DCP} 8.4 \%$, TDN 함량은 $57 \%$ 로 본 실험의 옥 수수 사일리지 보다 $\mathrm{DCP}$ 는 높게, $\mathrm{TDN}$ 은 낮게 평가되었다. 농후사료 단독급여에 의한 평가에 서는 $\mathrm{DCP} 10.9 \%$, TDN $81 \%$ 이었다.

2. 에너지 균형

각 사료조합별 유지에너지 급여 수준에 따른 대사체중당 에너지 섭취량 및 열 발생량 및 에 너지균형은 Table 1, 2, 3, 4에 나타냈다. 유지 를 위한 대사에너지 요구량은 대사에너지 섭취

Table 1. Intake of $\mathrm{DE}$ and $\mathrm{ME}$, heat production and energy balance $\left(\mathrm{kcal} / \mathrm{W}^{0.75}\right)$ measured at maintenance level of Hanwoo bulls at $100 \mathrm{~kg}$ body weight

\begin{tabular}{cccrrr}
\hline \multirow{2}{*}{ Feeds } & $\begin{array}{c}\text { GE } \\
\text { intake }\end{array}$ & $\begin{array}{c}\text { DE } \\
\text { intake }\end{array}$ & \multicolumn{1}{c}{$\begin{array}{c}\text { ME } \\
\text { intake }\end{array}$} & \multicolumn{1}{c}{$\begin{array}{c}\text { Heat } \\
\text { production }\end{array}$} & \multicolumn{1}{c}{$\begin{array}{c}\text { Retained } \\
\text { energy }\end{array}$} \\
\hline \hline I & $183.31 \pm 0.70$ & $112.01 \pm 3.34$ & $98.49 \pm 4.01$ & $110.59 \pm 8.97$ & $-12.11 \pm 12.97$ \\
II & $197.83 \pm 0.50$ & $128.70 \pm 3.73$ & $116.78 \pm 3.81$ & $98.99 \pm 2.42$ & $17.79 \pm 1.40$ \\
III & $202.82 \pm 1.32$ & $129.22 \pm 8.09$ & $105.08 \pm 12.06$ & $106.02 \pm 2.74$ & $-0.94 \pm 9.50$ \\
IV & $190.89 \pm 5.54$ & $87.14 \pm 6.53$ & $79.77 \pm 6.46$ & $89.59 \pm 1.65$ & $-5.82 \pm 5.22$ \\
V & $243.47 \pm 5.11$ & $131.12 \pm 5.63$ & $119.41 \pm 5.34$ & $108.30 \pm 6.45$ & $11.11 \pm 1.47$ \\
VI & $190.56 \pm 1.29$ & $102.18 \pm 1.14$ & $85.20 \pm 3.42$ & $94.57 \pm 4.13$ & $-9.37 \pm 4.94$ \\
VII & $168.95 \pm 1.07$ & $135.23 \pm 2.05$ & $121.42 \pm 1.78$ & $104.19 \pm 8.26$ & $17.22 \pm 7.47$ \\
\hline
\end{tabular}

Mean \pm SE. 
Table 2. Intake of $\mathrm{DE}$ and $\mathrm{ME}$, heat production and energy balance $\left(\mathrm{kcal} / \mathrm{W}^{0.75}\right)$ measured at maintenance level of Hanwoo bulls at $200 \mathrm{~kg}$ body weight

\begin{tabular}{cccccc}
\hline \multirow{2}{*}{ Feeds } & $\begin{array}{c}\text { GE } \\
\text { intake }\end{array}$ & $\begin{array}{c}\text { DE } \\
\text { intake }\end{array}$ & $\begin{array}{c}\text { ME } \\
\text { intake }\end{array}$ & $\begin{array}{c}\text { Heat } \\
\text { production }\end{array}$ & $\begin{array}{c}\text { Retained } \\
\text { energy }\end{array}$ \\
\hline \hline I & $198.16 \pm 1.62$ & $132.64 \pm 2.54$ & $112.87 \pm 3.80$ & $110.09 \pm 3.69$ & $2.78 \pm 5.39$ \\
II & $209.81 \pm 0.61$ & $144.69 \pm 1.00$ & $127.65 \pm 1.36$ & $115.94 \pm 1.31$ & $11.71 \pm 2.61$ \\
III & $179.31 \pm 3.15$ & $129.47 \pm 1.05$ & $115.60 \pm 1.39$ & $101.85 \pm 1.61$ & $13.75 \pm 2.73$ \\
IV & $200.10 \pm 2.63$ & $116.21 \pm 5.10$ & $107.38 \pm 2.87$ & $109.70 \pm 6.27$ & $-2.37 \pm 3.40$ \\
V & $262.89 \pm 3.30$ & $162.00 \pm 3.26$ & $86.89 \pm 3.02$ & $87.31 \pm 3.43$ & $-0.42 \pm 5.96$ \\
VI & $184.67 \pm 2.22$ & $118.56 \pm 4.96$ & $101.17 \pm 4.87$ & $104.44 \pm 5.59$ & $-3.27 \pm 7.25$ \\
VII & $174.43 \pm 3.05$ & $143.61 \pm 3.93$ & $132.58 \pm 5.83$ & $117.58 \pm 3.34$ & $15.00 \pm 2.79$ \\
\hline
\end{tabular}

Mean \pm SE.

Table 3. Intake of $\mathrm{DE}$ and $\mathrm{ME}$, heat production and energy balance $\left(\mathrm{kcal} / \mathrm{W}^{0.75}\right)$ measured at maintenance level of Hanwoo bulls at $300 \mathrm{~kg}$ body weight

\begin{tabular}{cccccc}
\hline \multirow{2}{*}{ Feeds } & $\begin{array}{c}\text { GE } \\
\text { intake }\end{array}$ & $\begin{array}{c}\text { DE } \\
\text { intake }\end{array}$ & $\begin{array}{c}\text { ME } \\
\text { intake }\end{array}$ & $\begin{array}{c}\text { Heat } \\
\text { production }\end{array}$ & $\begin{array}{c}\text { Retained } \\
\text { energy }\end{array}$ \\
\hline \hline I & $200.55 \pm 1.73$ & $116.81 \pm 5.78$ & $102.33 \pm 6.12$ & $103.04 \pm 4.79$ & $-0.71 \pm 7.25$ \\
II & $159.91 \pm 1.51$ & $105.29 \pm 0.43$ & $90.77 \pm 1.71$ & $100.36 \pm 2.74$ & $-9.59 \pm 1.34$ \\
III & $158.90 \pm 2.08$ & $110.71 \pm 5.96$ & $92.55 \pm 6.40$ & $103.39 \pm 2.61$ & $-10.85 \pm 4.89$ \\
IV & $216.06 \pm 2.85$ & $106.97 \pm 6.22$ & $92.93 \pm 6.70$ & $93.50 \pm 2.19$ & $-0.57 \pm 7.33$ \\
V & $183.09 \pm 1.99$ & $109.05 \pm 0.89$ & $92.68 \pm 2.65$ & $89.86 \pm 5.18$ & $2.83 \pm 7.18$ \\
VI & $174.98 \pm 5.64$ & $102.44 \pm 6.89$ & $85.28 \pm 8.26$ & $94.95 \pm 5.12$ & $-9.67 \pm 7.55$ \\
VII & $138.75 \pm 0.83$ & $104.55 \pm 4.29$ & $81.84 \pm 6.62$ & $85.53 \pm 2.75$ & $-3.69 \pm 6.29$ \\
\hline
\end{tabular}

Mean \pm SE.

Table 4. Intake of $\mathrm{DE}$ and $\mathrm{ME}$, heat production and energy balance $\left(\mathrm{kcal} / \mathrm{W}^{0.75}\right)$ measured at maintenance level of Hanwoo bulls at $400 \mathrm{~kg}$ body weight

\begin{tabular}{cccccc}
\hline \multirow{2}{*}{ Feeds } & $\begin{array}{c}\text { GE } \\
\text { intake }\end{array}$ & $\begin{array}{c}\text { DE } \\
\text { intake }\end{array}$ & $\begin{array}{c}\text { ME } \\
\text { intake }\end{array}$ & $\begin{array}{c}\text { Heat } \\
\text { production }\end{array}$ & $\begin{array}{c}\text { Retained } \\
\text { energy }\end{array}$ \\
\hline \hline I & $170.50 \pm 1.20$ & $101.96 \pm 2.18$ & $81.13 \pm 1.17$ & $96.44 \pm 2.34$ & $-15.31 \pm 3.49$ \\
II & $160.49 \pm 1.35$ & $111.89 \pm 2.05$ & $91.81 \pm 1.89$ & $106.46 \pm 3.26$ & $-14.65 \pm 1.48$ \\
III & $176.53 \pm 4.03$ & $123.10 \pm 3.68$ & $102.82 \pm 1.17$ & $113.06 \pm 2.34$ & $-10.24 \pm 3.49$ \\
IV & $204.22 \pm 1.30$ & $121.09 \pm 5.29$ & $107.77 \pm 5.69$ & $102.00 \pm 0.71$ & $5.77 \pm 4.98$ \\
V & $185.20 \pm 1.11$ & $112.86 \pm 1.61$ & $96.54 \pm 3.06$ & $91.12 \pm 1.54$ & $5.42 \pm 1.86$ \\
VI & $196.36 \pm 5.55$ & $123.17 \pm 7.45$ & $103.95 \pm 7.39$ & $97.99 \pm 5.40$ & $5.96 \pm 2.55$ \\
VII & $142.87 \pm 0.25$ & $113.08 \pm 4.24$ & $95.58 \pm 1.50$ & $95.59 \pm 1.31$ & $-0.01 \pm 2.20$ \\
\hline
\end{tabular}

Mean \pm SE. 
량과 열 발생량이 균형이 잡히는, 즉 축적에너 지의 증가나 감소가 없는 양이다. 가소화에너 지 $(\mathrm{DE})$ 에서 뇨와 메탄으로 배출된 에너지를 뺀 대사에너지 $(\mathrm{ME})$ 는 체중과 사료조합에 따른 뚜렷한 차이를 볼 수 없었고, 대사체중 당 최 저 $79 \mathrm{kcal}$ 부터 최대 $132 \mathrm{kcal}$ 까지 섭취한 것으로 나타났다. 그러나 열 발생량은 대사체중 당 최 저 $85 \mathrm{kcal}$ 부터 $117 \mathrm{kcal}$ 의 범위를 보였고, 유지 에너지 요구량은 산술적 평균값인 $100.6 \mathrm{kcal}$ 정 도의 수준이 될 것임을 예측할 수 있다. 유지 수준이상의 에너지를 섭취하면 사료의 소화과 정에서 발생하는 열량증가(heat increment)로 열 발생량도 증가하게 되지만, 본 실험에서는 유 지수준의 에너지를 급여하였고, 대사에너지 섭 취량의 변이와 열 발생량의 변이는 개체 차이 가 크게 작용한 것으로 보인다.

\section{3. 근육활동에 대한 에너지 지출량}

절식시 체중별 기립시간과 소요 에너지 및 기복횟수에 따른 소요에너지의 체중별 모든 사 료의 평균값은 Table 5에 나타나 있다. 체중 $100 \sim 400 \mathrm{~kg}$ 에서의 24 시간 중 기립시간은 각각 평균 547, 347, 468 그리고 579분이었는데, 이
결과는 한우 성빈우를 가지고 시험한 탁 등 (1983)의 784분보다도 낮게 나타났다. Vercoe (1973)는 서 있을 때의 에너지 지출량이 누워 있을 때 보다 $18 \%$ 정도 많았으며 1 일 절식 체 중 $\mathrm{kg}$ 당 약 $3.3 \mathrm{kcal}$ 의 추가적인 에너지가 소 요된다고 하였으며, $\mathrm{ARC}(1980)$ 에서는 절식체중 이 아닌 사료급여 상태의 체중 $\mathrm{kg}$ 당 $2.39 \mathrm{kcal}$ 를 권장하였는데, 본 시험에서의 기립시간은 절식상태에서 측정되었기 때문에 $\operatorname{Vercoe}(1973)$ 의 결과를 본 시험의 기립 시간에 적용시켰을 때 기립시의 에너지 지출량은 체중 $100 \mathrm{~kg}$ 시 평균 $139 \mathrm{kcal}$, 체중 $200 \mathrm{~kg}$ 시 $215 \mathrm{kcal}, 300 \mathrm{~kg}$ 시 $468 \mathrm{kcal}, 400 \mathrm{~kg}$ 시 $784 \mathrm{kcal}$ 이었다.

기복시 일어설 때의 에너지 지출량이 앉을 때 보다 높지만, $\mathrm{ARC}(1980)$ 에서는 앉고 서는 것을 1 회 기복으로 보고 절식체중 $100 \mathrm{~kg}$ 당 $6.21 \mathrm{kcal}$ 의 에너지가 소요된다고 하였고, 본시 험에서 얻어진 기복횟수 7.0 회를 기복횟수에 적용시켰을 때 1 일 기복에 따른 에너지 지출량 역시 체중 $100 \mathrm{~kg}$ 시 평균 $51.17 \mathrm{kcal}$ 이고, 체중 $200 \mathrm{~kg}$ 에서 평균 $86.93 \mathrm{kcal}$, 체중 $300 \mathrm{~kg}$ 시 126.34 $\mathrm{kcal}, 400 \mathrm{~kg}$ 시 $181.77 \mathrm{kcal}$ 이었다. 이러한 결과 는 한우 성빈우를 가지고 행한 탁 등(1983)의 9회에 비해 다소 낮았던 것으로 나타났다.

Table 5. Time and energy cost for standing and energy cost for double act for fasted Hanwoo bulls at diffferent body weights

\begin{tabular}{ccccc}
\hline $\begin{array}{c}\text { Body } \\
\text { weight }\end{array}$ & Fasted wt. & $\begin{array}{c}\text { Standing } \\
\text { time }\end{array}$ & $\begin{array}{c}\text { Standing } \\
\text { energy cost }^{1)}\end{array}$ & $\begin{array}{c}\text { Energy cost }{ }^{2)} \text { for } \\
\text { double act }\end{array}$ \\
\hline \hline $\mathrm{kg}$ & $\mathrm{kg}$ & $\mathrm{min}$ & $\mathrm{kcal}$ & $\mathrm{kcal}$ \\
100 & $117.90 \pm 5.14$ & $547.07 \pm 56.21$ & $139.08 \pm 23.20$ & $51.17 \pm 1.91$ \\
200 & $201.89 \pm 2.31$ & $346.65 \pm 121.11$ & $215.17 \pm 17.15$ & $86.93 \pm 0.87$ \\
300 & $277.89 \pm 3.58$ & $468.02 \pm 164.79$ & $403.20 \pm 32.73$ & $126.34 \pm 1.63$ \\
400 & $360.44 \pm 10.48$ & $579.44 \pm 35.75$ & $784.62 \pm 93.38$ & $181.77 \pm 2.02$ \\
\hline
\end{tabular}

Mean \pm SE.

1) Adopted $3.3 \mathrm{kcal} / \mathrm{kg}$ fasted weight per $24 \mathrm{hrs}$ by Vercoe(1973).

2) Measured value for double action was 7.0 times per $24 \mathrm{hrs}$. adopted $6.21 \mathrm{kcal} / 100 \mathrm{~kg}$ fasted weight per double action by ARC(1980). 
4. 절식대사 및 유지시 정미에너지(NEm) 요 구량

각 체중에 있어서 절식대사량(절식시 열 발 생량; FHP), 기초대사량(basal metabolic rate) 및 $\mathrm{NEm}$ 요구량에 대한 모든 사료의 평균값은 Table 6에 나타나 있다. 각 사료 조합별로 유지수준 만을 섭취한 후 4 일(체중 $100 \mathrm{~kg}$ ) 또는 5 일(체중 $200,300,400 \mathrm{~kg}$ )간 절식시켰을 때, $\mathrm{FHP}$ 는 개 체간 차이가 많았다. Ritzman과 Benedict(1938) 는 건유우의 $\mathrm{FHP}$ 는 개체간의 차이는 물론 동 일한 개체에서도 시기를 달리하였을 경우 30 $80 \%$ 의 차이를 보였다고 하였으며 Brody (1945) 는 비유우의 FHP의 변이가 $\pm 15 \sim 25 \%$ 에 달하였 다고 하였다. 본 실험의 체중 $100 \mathrm{~kg}$ 에서는 FHP가 66.05/ $/ \mathrm{W}^{0.75}$ 로 높았으나, 체중 200 $400 \mathrm{~kg}$ 사이에서는 $60-63 \mathrm{kcal} / \mathrm{W}^{0.75}$ 로 거의 비슷 하였다. 이 값은 Ayshire를 가지고 행한 Blaxter 등(1966)의 $86 \mathrm{kcal} / \mathrm{W}^{0.75}$ 및 Shorthorn을 가지고 행한 Mitchell 과 Hamilton(1941)의 $74 \mathrm{kcal} / \mathrm{W}^{0.75}$ 보다 낮았으며 동일 체중에서의 $\mathrm{FHP}$ 를 $\mathrm{ARC}$ (1980)와 비교하면 약 $12 \%$ 낮게 나타났다. 품 종간의 절식대사량 차이를 비교한 몇가지 보고 를 참고할 때 Byers 등(1976)은 유우 품종의 경 우 대사적으로 활성적인 소화기관 및 간조직의 비율이 높아 단백질 turnover rate 가 육우 품종 에 비해 빠르기 때문에 FHP가 높았다고 하였
으며 Blaxter 등(1966)은 육우는 유우에 비해 대사량이 $19 \%$ 정도 낮았다고 보고하였다. 유우 끼리 비교를 한 Frisch(1970)은 Brahman $\times$ Britisch 거세우는 Africander $\times$ Shorthorn 거세 우보다 FHP이 낮았다고 하였다.

한편 FHP에서 근육 활동(muscular work), 즉 기립시간과 기복횟수에 소요된 에너지를 제외 한 기초대사량은 체중 $100 \quad 400 \mathrm{~kg}$ 에서 평균 $55.92 \mathrm{kcal} / \mathrm{W}^{0.75}$ 이었고, 稿瓜 등(1967)이 제시한 화우의 기초대사량 $54.28 \mathrm{kcal} / \mathrm{W}^{0.75}$ 및 탁 등 (1983) $53.32 \mathrm{kcal} / \mathrm{W}^{0.75}$ 보다 약간 높게 나타났 다.

기초대사량에 체조직의 분해산물로서 뇨 에 너지 배설량을 추가적으로 보정한 NEm 요구 량은 체중 $100 \mathrm{~kg}$ 에서 가장 높아 $69.10 \mathrm{kcal} /$ $\mathrm{W}^{0.75}$ 였으나, 체중 $200 \sim 400 \mathrm{~kg}$ 간에서는 62.07 $65.76 \mathrm{kcal} / \mathrm{W}^{0.75}$ 로서 체중간에 차이가 없었다. 절 식대사량을 근거로 측정된 $\mathrm{NEm}$ 요구량에 실 제 사양조건하에서 발생할 수 있는 임의 활동 (Voluntary activity)에 필요한 에너지 지출을 포 함한 요구량에 대한 안전율(일본사양표준, 2000) 을 $10 \%$ 정도 추가할 때 최종적인 $\mathrm{NEm}$ 요구량 을 $71.86 \mathrm{kcal} / \mathrm{W}^{0.75}$ 로 평가하는 것이 바람직할 것으로 사료된다.

평가된 $\mathrm{NEm}$ 요구량은 임의활동 및 개체간 변이를 함께 고려한 탁 등(1983)의 $65.73 \mathrm{kcal} /$ $\mathrm{W}^{0.75}$ 보다 높았고, TDN 요구량으로 부터 추정

Table 6. Fasting heat production(FHP), basal metabolic rate and net energy requirement for maintenance(NEm) measured for fasted Hanwoo bulls at different body weights

\begin{tabular}{cccccc}
\hline $\begin{array}{c}\text { Body } \\
\text { weight }\end{array}$ & FHP & $\begin{array}{c}\text { Energy expenses } \\
\text { as muscular work }\end{array}$ & $\begin{array}{c}\text { Basal } \\
\text { metabolic rate }\end{array}$ & $\begin{array}{c}\text { Urinary } \\
\text { energy }\end{array}$ & NEm \\
\hline \hline $\mathrm{kg}$ & $\mathrm{kcal} / \mathrm{W}^{0.75}$ & $\mathrm{kcal}$ & $\mathrm{kcal} / \mathrm{W}^{0.75}$ & $\mathrm{kcal} / \mathrm{W}^{0.75}$ & $\mathrm{kcal} / \mathrm{W}^{0.75}$ \\
100 & $66.05 \pm 5.27$ & $190.25 \pm 24.26$ & $62.35 \pm 5.66$ & $3.04 \pm 0.38$ & $69.10 \pm 5.69$ \\
200 & $59.77 \pm 1.22$ & $302.09 \pm 16.99$ & $54.47 \pm 1.15$ & $2.30 \pm 0.36$ & $62.07 \pm 1.26$ \\
300 & $62.81 \pm 1.50$ & $529.55 \pm 32.74$ & $55.47 \pm 1.52$ & $2.96 \pm 0.52$ & $65.76 \pm 1.57$ \\
400 & $62.41 \pm 3.07$ & $966.41 \pm 96.83$ & $51.40 \pm 3.27$ & $1.95 \pm 0.56$ & $64.37 \pm 3.32$ \\
\hline
\end{tabular}


할 때의 일본 화우 성빈우(일본사양표준, 1987) 의 $69.19 \mathrm{kcal} / \mathrm{W}^{0.75}$ 보다 약 $4 \%$ 높았다. 그러나 탁 등(1983) 및 일본사양표준(1987)의 성빈우 요구량을 가지고 동등한 조건하에서 비교를 하 기에는 다소 어려울 것 같다.

Vercoe(1970), Webster 등(1976) 및 Van Es (1980)의 보고에서는 숫소의 NEm 요구량은 암 소 또는 거세우 보다도 높았다고 하였으며 $\mathrm{ARC}(1980)$ 에서는 숫소의 경우 최대 $15 \%$ 까지 $\mathrm{NEm}$ 요구량이 증가되어져야 한다고 하였다. 그러나 $\mathrm{NRC(1984)에서는} \mathrm{성에} \mathrm{관계없이} 77$ $\mathrm{kcal} / \mathrm{W}^{0.75}$ 를 권장하였던 바, 본 시험 결과 보다 약 $9 \%$ 높았다. 그러나 $\mathrm{ARC}(1980)$ 의 평가 기초 자료에는 Ayshire와 Holstein과 같은 유우가 많 이 포함되어 있을 뿐 만아니라 만숙종인 대형 종 육우가 포함되어 있어 본 시험 결과와 직접 비교하기에는 어려울 것으로 사료되는데 유우 의 경우 육우와의 단백질 turnover rate 차이로 설명될 수 있으며(Byers 등, 1976; Van Es, 1980), 같은 육우 품종의 경우에는 지방 축적도 가 높은 소 즉, 조숙종의 $\mathrm{NEm}$ 요구량이 낮다 고 하며(Byers 등, 1976), $\mathrm{NRC}(1984)$ 에서도 조 숙종이나 $\mathrm{Zebu}$ 잡종의 경우 $77 \mathrm{kcal} / \mathrm{W}^{0.75}$ 보다 낮게 평가해줄 것을 권장하고 있다. 이런 관점 에서 볼 때 비교적 외형이나 지방축적 능력이
비교적 비슷한 한우와 화우의 요구량이 비슷하 게 평가되어진 것은 흥미로운 결과로 사료된 다.

\section{5. 유지시 대사에너지(MEm) 요구량}

각 사료조합중 유지량을 급여한 사료조합의 에너지 균형(Table 1, 2, 3, 4)에서 얻어진 에너 지 축적량(retained energy)과 보정 $\mathrm{NEm}$ 인 기초 대사시 열 발생량(Table 6)을 더하여 NE요구량 을 구하고, 섭취한 대사에너지가 $\mathrm{NE}$ 로 전환된 효율을 구하였다. 보정하여 에너지 평형상태로 환산한 평균 $\mathrm{MEm}$ 요구량은 Table 7에 나타나 있다.

본 실험결과의 전 체중 평균 $\mathrm{MEm}$ 요구량은 $102.69 \mathrm{kcal} / \mathrm{W}^{0.75}$ 로서 사료급여 수준을 달리 했 을 때의 에너지 축적량(이 등, 2002)으로부터 얻은 $95.80 \mathrm{kcal} / \mathrm{W}^{0.75}$ 보다 약 $7.2 \%$ 높게 나타 났으며, 한우 성빈우를 가지고 행한 탁 등 (1983)의 $85.59 \mathrm{kcal} / \mathrm{W}^{0.75}$ 및 화우 성빈우를 가 지고 행한 稿瓜 등(1967)의 $95.48 \mathrm{kcal} / \mathrm{W}^{0.75}$ 보 다 각각 $12 \%$ 와 $10.1 \%$ 씩 높았다. 또한 일본사 양표준(1987)에서는 $106.43 \mathrm{kcal} / \mathrm{W}^{0.75}$ 로 본시험 의 결과와 비슷하였으나 $\mathrm{NRC}(1984)$ 의 131 $\mathrm{kcal} / \mathrm{W}^{0.75}$ 보다는 $21 \%$ 낮았으며, $\mathrm{ARC}(1980)$ 의

Table 7. ME requirement for maintenance(MEm) measured for Hanwoo bulls at different body weights

\begin{tabular}{ccccccc}
\hline $\begin{array}{c}\text { Body } \\
\text { weight }\end{array}$ & $\begin{array}{c}\text { ME } \\
\text { intake }\end{array}$ & NEm & $\begin{array}{c}\text { Retained } \\
\text { energy }\end{array}$ & $\begin{array}{c}\text { NE value } \\
\text { of } \mathrm{ME}^{1)}\end{array}$ & $\begin{array}{c}\text { Deposit of } \\
\text { as } \mathrm{ME}^{2)}\end{array}$ & $\begin{array}{c}\text { MEm corrected } \\
\text { at zero }\end{array}$ \\
\hline \hline $\mathrm{kg}$ & $\mathrm{kcal} / \mathrm{W}^{0.75}$ & $\mathrm{kcal} / \mathrm{W}^{0.75}$ & $\mathrm{kcal} / \mathrm{W}^{0.75}$ & $\%$ & $\mathrm{kcal} / \mathrm{W}^{0.75}$ & $\mathrm{kcal} / \mathrm{W}^{0.75}$ \\
100 & $103.68 \pm 4.84$ & 69.10 & $2.55 \pm 6.14$ & $69.29 \pm 4.79$ & $3.09 \pm 9.72$ & $100.59 \pm 7.75$ \\
200 & $112.02 \pm 3.30$ & 62.07 & $3.89 \pm 4.02$ & $60.45 \pm 3.27$ & $7.45 \pm 7.35$ & $104.57 \pm 5.58$ \\
300 & $91.02 \pm 5.49$ & 65.77 & $-4.61 \pm 6.12$ & $66.43 \pm 3.91$ & $-8.75 \pm 9.03$ & $99.94 \pm 5.75$ \\
400 & $97.09 \pm 3.12$ & 64.37 & $-3.92 \pm 2.66$ & $62.71 \pm 2.02$ & $-7.05 \pm 4.87$ & $104.14 \pm 3.62$ \\
\hline
\end{tabular}

Mean \pm SE.

1) $(\mathrm{NEm}+$ Retained energy $) / \mathrm{MEI} \times 100$.

2) (Retained energy/NE value of $\mathrm{ME}) \times 100$.

3) MEI - Deposit as ME. 
대사율 0.6 을 기준으로 할 때 동일 체중 비교 에서는 $20 \%$ 낮게 평가되었다.

\section{6. 유지시 가소화 에너지(DEm)및 TDNm 요 구량}

체중에 따른 각 사료 조합별 유지량 급여 성 적에서의 에너지 균형 성적과 $\mathrm{NEm}$ 요구량으 로 부터 유지를 위한 가소화에너지(DEm)과 $\mathrm{TDNm}$ 요구량을 구해본 결과, 즉, 에너지 균형 성적으로부터 결핍된 가소화에너지(DE)의 대사 에너지(ME)로의 전환효율 $(\mathrm{ME} / \mathrm{DE})$ 를 $\mathrm{MEm}$ 요 구량에 적용시켜 $\mathrm{DEm}$ 요구량을 산출하였는 데 체중 100 400 kg 까지의 체중별 DEm 요구 량은 $117.89 \sim 123.74 \mathrm{kcal} / \mathrm{W}^{0.75}$ 의 범위에 있었으 며 평균 $120.92 \mathrm{kcal} / \mathrm{W}^{0.75}$ 였다. 이 양은 실제 기 대치보다 낮았는데, 그 이유는 본 시험에서의 $\mathrm{ME} / \mathrm{DE}$ 는 0.86 으로서 $\mathrm{NRC}(1984)$ 에서 채택하고 있는 계수 0.82 보다 다소 높기 때문이다. 따라 서 계수 0.82 를 적용할 경우 $126.25 \mathrm{kcal} / \mathrm{W}^{0.75}$ 가 된다. 한편, $\mathrm{TDNm}$ 요구량은 $\mathrm{ME}$ 의 $\mathrm{TDN}$ 전환 효율(TDN/ME)로 부터 산출하였는데 체중 100 $\sim 400 \mathrm{~kg}$ 까지의 체중별 요구량은 $26.45 \sim 28.01 \mathrm{~g} /$ $\mathrm{W}^{0.75}$ 이었다. 본 시험에서의 $\mathrm{TDN} / \mathrm{ME}$ 는 평균 0.26 으로서 이를 $\mathrm{ME} / \mathrm{TDN}$ 으로 바꾸어볼 때 3.864 가 되어 $\mathrm{NRC}(1976)$ 의 3.616 보다 효율이 다소 높았던 것으로 나타났다.

\section{7. 유지시 건물요구량 및 사료에너지가}

체중에 따른 각 사료조합별 유지시 건물 요 구량 및 사료 에너지가를 계산해 보면, 체중 $100 \sim 400 \mathrm{~kg}$ 까지의 유지시 건물요구량은 41.93 $\sim 55.50 \mathrm{~g} / \mathrm{W}^{0.75}$ 의 범위에 있었으며 평균 43.32 $\mathrm{g} / \mathrm{W}^{0.75}$ 이었다. 이 값은 사양시험을 근거로 하 여 평가한 일본사양표준(1987)의 화우 수소의 $68 \mathrm{~g} / \mathrm{W}^{0.75}$ 보다 매우 낮았는데 여기에는 대사 시험과 사양시험을 실시한 환경 조건도 많은 영향을 미쳤을 것이라 사료된다.
에너지 표현 단위에 관계없이 각 조사료+배 합사료의 혼합사료조합의 에너지가는 조사료의 특성에 영향을 받아 대체적으로 옥수수 사일리 지+배합사료, 건초+배합사료 및 볏짚+배합사료 의 순으로 높았으며 이들의 평균 $\mathrm{NE}$ 가는 각각 $1.07 \sim 1.18 \mathrm{Mcal} / \mathrm{kg}, 1.27 \sim 1.78 \mathrm{Mcal} / \mathrm{kg}$ 및 1.52 $1.81 \mathrm{Mcal} / \mathrm{kg}$ 이었다. 볏짚의 경우 $\mathrm{DE}, \mathrm{ME}$ 및 $\mathrm{NEm}$ 이 각각 $2.13 \mathrm{Mcal} / \mathrm{kg}(1.85 \sim 2.47 \mathrm{Mcal} / \mathrm{kg})$, $1.91 \mathrm{Mcal} / \mathrm{kg}(1.69 \sim 2.03 \mathrm{Mcal} / \mathrm{kg})$ 및 $1.21 \mathrm{Mcal} /$ $\mathrm{kg}(1.13 \sim 1.36 \mathrm{Mcal} / \mathrm{kg})$ 으로서 $\mathrm{NRC}(1984)$ 에서 제 시한 볏짚의 $\mathrm{DE} 1.81 \mathrm{Mcal} / \mathrm{kg}$, ME $1.48 \mathrm{Mcal} /$ $\mathrm{kg}, \mathrm{NEm} 0.64 \mathrm{Mcal} / \mathrm{kg}$ 와 한국표준사료성분표 (1988)의 DE $1.91 \mathrm{Mcal} / \mathrm{kg}$, ME $1.56 \mathrm{Mcal} / \mathrm{kg}$, $\mathrm{NEm} 0.56 \mathrm{Mcal} / \mathrm{kg}$ 와 한국사료성분표(1982)의 $\mathrm{DE} 1.91 \mathrm{Mcal} / \mathrm{kg}$ 을 제외한 $\mathrm{ME} 1.69 \mathrm{Mcal} / \mathrm{kg}$ 및 NEm $0.93 \mathrm{Mcal} / \mathrm{kg}$ 보다도 높게 나타났는데, 특히 $\mathrm{NEm}$ 에서 차이가 많이 나타난 것은 볏짚 급여시 예상 밖으로 높았던 $\mathrm{Km}$ 에 영향을 받았 던 것으로 사료된다. 그러나 건초는 한국표준 사료성분표(1988)의 혼합목초(오차드 주종, 출 수전)와 한국사료성분표(1982)의 오차드그라스 - 클로우버 건초와 거의 비슷한 DE $2.53 \mathrm{Mcal} /$ $\mathrm{kg}(2.19 \sim 2.82 \mathrm{Mcal} / \mathrm{kg}), \quad \mathrm{ME} 2.20 \mathrm{Mca} / \mathrm{kg}(1.97 \sim 2.41$ $\mathrm{Mcal} / \mathrm{kg}), \quad \mathrm{NEm} \quad 1.40 \mathrm{Mcal} / \mathrm{kg}(1.06 \sim 1.53 \mathrm{Mcal} / \mathrm{kg})$ 을 보여 주었다. 옥수수사일리지는 $\mathrm{NRC}(1984)$ 와 한국사료성분표(1982)에서 제시하고 있는 황숙기와 유숙기 옥수수 사일리지의 중간값을 나타냈고, 한국표준 사료성분표(1988)의 황숙기 사일리지와 비슷한 결과를 보였다.

\section{IV. 요 약}

한우 수소의 유지를 위한 정미에너지 및 대 사에너지를 구하기 위하여 28 회의 절식대사 시 험을 수행하였다. 체중 $100 \mathrm{~kg}$ 에서 $400 \mathrm{~kg}$ 까지 $100 \mathrm{~kg}$ 증체 간격 $(100,200,300,400 \mathrm{~kg})$ 으로 7종류의 사료를 각각 유지에너지 수준만 급여 하여 분뇨채취를 위한 대사시험(5일)과 열 발 생량 측정을 위한 호흡대사시험(2일)을 수행한 
후 다시 5일간 완전 절식시켜 마지막 24시간 동안 호흡대사시험을 실시하였다. 3종의 사료 는 배합사료+볏짚(실험 I), 배합사료+목건초(실 험 II), 배합사료+옥수수 사일리지(실험 III)이었 고, 조사료와 농후사료의 비율은 40:60으로 하 였다. 실험 IV, V, VI, VII은 각각 볏짚, 목건 초, 옥수수 사일리지, 배합사료를 단독 급여하 였다.

체중 $100 \mathrm{~kg}$ 에서는 절식대사량이 $66.05 / \mathrm{W}^{0.75}$ 로 높았으나, 체중 $200 \sim 400 \mathrm{~kg}$ 사이에서는 60 $63 \mathrm{kcal} / \mathrm{W}^{0.75}$ 로 거의 비슷하였다. 절식대사량에 서 절식시 근육 활동(기립시간과 기복횟수)에 소요된 에너지를 제외한 체중 $100 \sim 400 \mathrm{~kg}$ 의 평 균 기초대사량은 $55.92 \mathrm{kcal} / \mathrm{W}^{0.75}$ 이었다. 절식대 사량에 체조직의 분해산물로서 뇨 에너지 배설 량을 추가적으로 보정한 NEm 요구량은 체중 $100 \mathrm{~kg}$ 에서 가장 높아 $69.10 \mathrm{kcal} / \mathrm{W}^{0.75}$ 였으나, 체 중 $200 \sim 400 \mathrm{~kg}$ 간에서는 $62.07 \sim 65.76 \mathrm{kcal} / \mathrm{W}^{0.75}$ 로서 체중간에 차이가 없었다.

각 사료조합중 유지량을 급여한 사료조합의 에너지 균형에서 얻어진 에너지 축적량(retained energy)과 보정 $\mathrm{NEm}$ 인 기초대사시 열 발생량 으로 섭취한 대사에너지를 에너지 평형상태로 환산한 결과, 전 체중 평균 $\mathrm{MEm}$ 요구량은 $102.69 \mathrm{kcal} / \mathrm{W}^{0.75}$ 이었다.

\section{$\mathrm{V}$. 인 용 문 헌}

1. A. O. A. C. 1990. "Official Methods of Analysis" 15th ed. Association of Official Analytical Chemists. Washington, D. C.

2. Agricultural Research Council. 1980. The Nutrient requirements of Ruminant Livestock, Technical Reviews by an Agricultural Research Council Working Party. ARC, Farmham Royal, England.

3. Blaxter, K. L., Clapperton, J. L. and Wainman, F. W. 1966. Utilization of the energy and protein of the same diet by cattle and sheep. J. Agric. Sci. Camb. 67:67-75.

4. Brody, S. 1945. Bioenergetic and growth.
Reinhold Plub. Co., New York.

5. Brouwer, E. 1965. "Report of sub-committee on constants and factors" In : Energy Metabolism of Farm Animals. K.L. Blaxter (Ed.), 3rd symposium, Troon, p.441-444.

6. Byers, F. M., Johnson, D. E. and Matsushima, J. K. 1976. Associative effects between corn and corn silage on energy partitioning by steers (Eds. M. Vermorel. p.253-256. 7th Symposium, Vichy, p. $225-228$.

7. Mitchell, H. H. and Hamilton, T. S. 1941. The utilization by calves of the energy contained in balanced rations composed of combination of different feeds. J. Nutr. 22:541.

8. National Research Council. 1976. Nutrient requirements of Domestic Animals: Nutrient requirements of beef cattle. 5th ed. NAS-NRC, Washinton, D.C.

9. National Research Council. 1984. Nutrient requirements of Domestic Animals: Nutrient requirements of beef cattle. 6th ed. NAS-NRC, Washinton, D.C.

10. Ritzman, E. G. and Benedict, F. G. 1938. Nutritional physiology of the adult ruminant. Carnegie Inst. Washington, D.C. Plub.

11. Van Es, A. J. H. 1980. Net requirements for maintenance as dependent on weight, feeding level, sex and genotype, estimated from balance trials. In Energy and Protein Fedding standard Applied to the Rearing and Finishing of Beef Cattle. C. Beranger (Ed) Ann. Zootechnie 29, No.h.s. p.73-84.

12. Vercoe, J. E. 1970. Fasting metabolism and heat increment of feeding in Brahman $\times$ British cross cattle. In Energy metabolism of Farm Animals. A. Schurch and C. Wenk. Zurich, Juris Druck (Eds). 5th symposium, Vitznau, p. 85-88.

13. Vercoe, J. E. 1973. The energy cost of standing and lying and adult cattle. Brit. J. Nutr. 30: 207-210.

14. Webster, A. J. F., Gordon, J. G. and Smith, J. S. 1976b. Energy exchanges of veal calves in relation to body weight, food intake and air temperature. Anim. Prod. 23:35-42. 
15. 農林水産技術會議事務局：日本飼養標準, 肉用 牛. (1987년판), 中央畜産會. 1987.

16. 農林水産技術會議事務局：日本飼養標準，肉用 牛. (2000년판), 中央畜産會. 2000.

17. 橋瓜德三，針生程吉，伊藤 稔，增淵敏彦，田邊 忍，森本 宏. 1967. 肉牛の 飼養標準に 關する 研究. II. 和牛の 維持養分要求量に 關する 研 究. 畜試㸴報. 13:23-40.

18. 이상철. 1991. 한우 수소의 유지 및 증체시 에너 지 대사와 단백질 이용효율에 관한 연구. 서울대 학교 박사학위 논문.
19. 이상철, 탁태영, 김경훈, 윤상기. 2002. 에너지 균 형법에 의한 한우 수소의 유지 대사에너지 요구 량. 한국동물자원과학회지. 45(1):123-130

20. 탁태영, 강태홍, 김강식. 1983. 대사시험에 의한 한우 성빈우 유지시 양분요구량에 관한 연구. 한 축지 25(2):117-137.

21. 한국사료성분표. 1982. 한국 사료정보센타, 국제 사료연구소.

22. 한국표준사료성분표. 1988. 농촌진흥청 축산시험 장.

(접수일자 : 2002. 11. 4 / 채택일자 : 2003. 1. 24) 